\title{
The Scottish Painters' Exile in Italy in the Eighteenth Century
}

L'exil des peintres écossais en Italie au dix-huitième siècle

\section{Marion Amblard}

\section{(2) OpenEdition \\ 12 Journals}

Electronic version

URL: https://journals.openedition.org/etudesecossaises/219

DOI: $10.4000 /$ etudesecossaises. 219

ISSN: 1969-6337

Publisher

UGA Éditions/Université Grenoble Alpes

\section{Printed version}

Date of publication: 30 September 2010

Number of pages: $59-77$

ISBN: 978-2-84310-173-1

ISSN: $1240-1439$

Electronic reference

Marion Amblard, "The Scottish Painters' Exile in Italy in the Eighteenth Century", Études écossaises

[Online], 13 | 2010, Online since 30 September 2011, connection on 11 April 2023. URL: http://

journals.openedition.org/etudesecossaises/219; DOl: https://doi.org/10.4000/etudesecossaises.219

All rights reserved 


\section{The Scottish painters' exile in Italy in the eighteenth century}

In the eighteenth century, a visit to Italy was considered by many as essential in the career of a painter. Although contemporary Italian painting was not as prestigious as before, Rome was still the artistic centre of continental Europe and attracted many artists eager to complete their training and to find patrons among the aristocrats on the Grand Tour. ${ }^{1}$ As President of the Royal Academy, Joshua Reynolds (1723-1792) stressed the importance of a stay in Italy to enable young painters to study the works of the Renaissance masters. ${ }^{2}$ Not all English artists agreed with Reynolds; William Hogarth (1697-1764), for instance, staunchly opposed the idea of going abroad to copy and imitate foreign artists. ${ }^{3}$ For Scottish painters,

1. For more on the British and the Grand Tour, see Jeremy Black, The British Abroad: The Grand Tour in the Eighteenth Century, New York, Saint Martin's Press, 1992 and Christopher Hibbert, The Grand Tour, London, Thames Methuen, 1969. To know more specifically about the Scots in Italy, see Basil Skinner, Scots in Italy in the 18th Century, Edinburgh, Scottish National Portrait Gallery, 1966 and Richard Adam Marks, "The Scots in the Italian Peninsula during the Thirty Years' War", The Ulster Earls and Baroque Europe: Refashioning Irish Identities, 1600-1800, Thomas O'Connor and Mary Ann Lyons (eds), Dublin, Four Courts Press, 2009, pp. 336-8.

2. Reynolds told the students of the Royal Academy: "study [...] the great works of the great masters, for ever. Study as nearly as you can, in the order, in the manner, and on the principles, on which they studied." (Sir Joshua Reynolds, Discourses on Art, New Haven-London, Yale University Press, 1975, p. 113.)

In the discourses he delivered at the Royal Academy, Reynolds often praised the Renaissance masters. He admired above all Raphael and Michelangelo as he wrote that "these two extraordinary men $[\ldots]$ certainly have not been excelled, nor equalled since". (Sir Joshua Reynolds, Discourses on Art, p. 84.)

3. According to Hogarth, painters should be inspired by nature and not by the works of their illustrious predecessors. In his Analysis of Beauty he explained: "It is [...] evident that the painter's eye may not be a bit better fitted to receive these new impressions, who is in the like manner too much captivated with the works of art. [...] This mistake happens chiefly to those who go to Rome for the accomplishment of their studies, as they naturally will, without the utmost care, take the infectious turn of the connoisseur, instead of the painter: and in proportion as they turn by those means bad proficients in their own arts, they become the more considerable in that of a connoisseur. [...] It has ever been observed at all auctions of pictures, that the very worst painters sit as the most profound judges." (William Hogarth, The Analysis of Beauty, Written with a View of Fixing the Fluctuating Ideas of Taste, London, 1810, p. 5.) 
travelling to Italy was of prime importance as this was the means to complete the basic training acquired in their native country. Indeed, before 1798, there was no permanent fine art academy in Scotland; thus to get thorough artistic training they had to leave Scotland, so they either went to London or they studied in Italy. This was not a phenomenon confined to Caledonian artists. Indeed most eighteenth-century Irish and English painters undertook similar journeys to the Continent. Like the Scots, Irish painters did not have access to comprehensive training in their native country: until the middle of the eighteenth century, there was no art school in Ireland, so young Irishmen aspiring to an artistic career trained with craftsmen or went to England to work in the studio of a painter. ${ }^{4}$ The first Irish fine art institution was a drawing school opened in Dublin by Robert West (died 1770) in 1746. The school was taken over by the Dublin Society in 1750 and by 1759 two other schools had been set up - the Landscape and Ornament School and the Architectural School - in order to further develop the fine arts in Ireland. In England, painters had several options for training. In London they could join the studio of a famous artist and they could study in one of the fine art schools. Sir Godfrey Kneller (1646-1723) opened the first academy of painting in London in 1711; in 1720, Louis Chéron (1660-1725) and John Vanderbank (1694-1739) founded their own academy in Saint Martin's Lane and, from 1735, painters could study at the Saint Martin's Lane Academy set up by Hogarth with a group of artists. In addition, from 1768 onwards, artists could also become students at the Royal Academy. Yet most English painters still felt the need to go to the Continent because they believed, as did the majority of Western European artists, that their training could not be complete without a visit to Italy. Thus, on the Continent, Irish, English and Scottish painters worked side by side with artists from all over Europe. ${ }^{5}$

This article will investigate the role of the period of "exile" these Scottish painters spent in Italy during the eighteenth century and, through their return, underline the contribution of Italian art to the development of painting in Scotland. Until the publication of Scottish Painters at Home and Abroad 1700-1900 by David and Francina Irwin in 1975, Scottish art historians had reaffirmed the isolated position of Scottish painting vis-a-vis

4. For instance, Nathaniel Hone (1718-1784) was apprenticed to an enamellist whereas Charles Jervas (c. 1675-1739) went to London to become the pupil and assistant of Sir Godfrey Kneller.

5. According to David Irwin, the majority of painters who went to Italy in the eighteenth century came from the British Isles, France and Germany (David Irwin, Neoclassicism, London, Phaidon, 2000, p. 13). If Italy was the country they visited the most, John Wraight has shown that Switzerland was also a popular destination for British painters (Sir John Wraight, The Swiss and the British, Salisbury, M. Russell, 1987, p. 42-8). 
mainstream European art by downplaying or denying foreign influences. ${ }^{6}$ Because of commercial and cultural bonds between Scotland and the Dutch Republic dating back to the medieval period, Scottish painting has usually been compared with Dutch painting. ${ }^{7}$ The affinities between Scottish art and Dutch art were highlighted in the exhibition entitled Dutch Art and Scotland: a Reflection of Taste which was held at the National Gallery of Scotland in 1992. In the exhibition catalogue, Lindsay Errington claimed that:

Scottish painters have looked towards and learnt from Dutch artists over a long period of time. In the seventeenth and early eighteenth centuries, before romanticism fostered the idea of a national school of painting that might reflect national history and cultural identity, those Scottish painters who had learnt their skills from Dutch examples produced paintings with little to distinguish them from works produced in Holland. ${ }^{8}$

Indeed, the influence of Dutch art is particularly noticeable in seventeenth and early eighteenth-century Scottish paintings. Several Dutch portrait painters worked in Scotland in the seventeenth century and their style deeply impressed Scottish painters: King James VI (1566-1625) sat for two Dutch portraitists, Arnold Bronckorst (active 1565/15661583) and Adrian Vanson (active 1581-1602). At the time, Scotland was not lacking in native painters, but as most of them were trained as craftsmen they specialised in decorative painting and were unable to

6. David and Francina Irwin, Scottish Painters at Home and Abroad 1700-1900, London, Faber and Faber, 1975. The Irwins were the first scholars to set Scottish painting in a broader British and European context. In their study, they denounced "the chauvinistic tendency of Scottish writers around 1900 and since to see it as an isolated phenomenon" (David and Francina Irwin, Scottish Painters at Home and Abroad 1700-1900, p. 35).

Before 1975, art historians shared Brydall's opinion who wrote: "In England, almost to the present day, the influence is felt of Vandyke, Kneller, and other foreigners; but in Scotland there is little indication of foreign influence, except in some of the works of Jamesone, prior to the year 1630." (Robert Brydall, Art in Scotland. Its Origin and Progress, Edinburgh, William Blackwood and Sons, 1889, p. 218.)

Scottish painting is also studied in a European context in Marion Amblard, "The Scottish School's Contribution to the Development of European Painting: Exchanges and Interactions between Scottish and European Painters in the Eighteenth Century", Scotland and Europe, Scotland in Europe, Gilles Leydier (ed.), Newcastle, Cambridge Scholars Publishing, 2007, pp. 56-68.

7. For detailed studies on the links between Scotland and the Dutch Republic, as well as on the Scottish communities in the Dutch Republic, see Douglas Catterall, Community Without Borders: Scots Migrants and the Changing Face of Power in the Dutch Republic, c. 1600-1700, Leiden, Brill, 2002 and Alexia Grosjean and Steve Murdoch (eds), Scottish Communities Abroad in the Early Modern Period, Leiden, Brill, 2005, especially the chapters by Douglas Catterall, Ginny Gardner, Andrew Little and Esther Mijers.

8. Lindsay Errington, "Gold and Silver in Shadow. The Dutch Influence on Nineteenth-Century Scottish Painting", Dutch Art and Scotland. A Reflection of Taste, Julia Lloyd Williams (ed.), Edinburgh, the Trustees of the National Galleries of Scotland, 1992, p. 49. 
paint official portraits of the monarch. ${ }^{9}$ The influence of another Dutch painter, Adam de Colone (active 1622-1628) who worked in Edinburgh for several years, can also be seen in the works of George Jamesone (1589/1590-1644), the first major Scottish portraitist. ${ }^{10}$ Further, the influence of Dutch painting is also visible in still-lifes painted by early eighteenth-century Scottish painters such as Thomas Warrender (active 1673-1713) and Richard Waitt (active 1708-1732), who had certainly seen Dutch still-lifes imported by Scottish aristocrats. ${ }^{11}$ Several art historians have also stressed the influence of Flemish and French arts on Scottish painting. Among others, Sir David Wilkie (1785-1841) has often been compared to the Flemish painter David Teniers (1610-1690) and some of the Glasgow Boys' paintings are reminiscent of the works of the French naturalist painters. ${ }^{12}$ In 2009, the influence of Spanish art on nineteenth-century Scottish painters was stressed by the exhibition The Discovery of Spain. British Artists and Collectors: from Goya to Picasso held at the National Gallery of Scotland. ${ }^{13}$ However, so far, the influence of Italian art on eighteenth-century Scottish painting has been overlooked.

The first part of this article deals with the need for Scottish painters to take voluntary exile abroad in order to complete their training. By drawing up a list of Scottish painters who travelled to Italy in the eighteenth century and of the places they visited, we can see that the majority of Scottish painters trained in Italy. To study Italian painting, they travelled around the country which was then divided into several duchies and kingdoms.

9. For a detailed account on painting in seventeenth-century Scotland, see Duncan Thomson, Painting in Scotland 1570-1650, Edinburgh, The Trustees of the National Galleries of Scotland, 1975. See also Michael R. Apted and Susan Hannabuss, Painters in Scotland, 1300-1700: A Biographical Dictionary, Edinburgh, Edinburgh Scottish Record Society, 1978.

10. Thomson demonstrated that several features of the portraits of Mary Erskine, Countess of Marischal (1626, National Gallery of Scotland, Edinburgh) and of James Graham, 1st Marquess of Montrose (1629, the Earl of Southesk) derive from the influence of de Colone (Duncan Thomson, Painting in Scotland 1570-1650, pp. 61-2).

11. These paintings were imported from the Dutch Republic or from London, where several Dutch still-life painters worked. Waterhouse has explained that "Lord Lothian seems to have been a particular patron of this kind of painting, for there remain at Newbattle Abbey examples of Roestraeten and Collier and the solitary signed 'Flower Piece' of B. Ferrers dated 1695." (Ellis Waterhouse, Painting in Britain 1530-1790, New Haven-London, Yale University Press, 1994, p. 116.)

Thomas Warrender's Still Life (1708, National Gallery of Scotland, Edinburgh) is particularly redolent of Collier's still-lifes.

12. Harry Mount, "'Our British Teniers': David Wilkie and the Heritage of Netherlandish Art", David Wilkie. Painter of Everyday Life, Nicholas Tromans (ed.), London, Dulwich Picture Gallery, 2002, pp. 30-9.

Roger Billcliffe, The Glasgow Boys. The Glasgow School of Painting 1875-1895, London, John Murray, 2002.

13. The Discovery of Spain. British Artists and Collectors: from Goya to Picasso, exhibition held at the National Gallery of Scotland from 18 July to 11 October 2009. The exhibition especially stressed the fact that Wilkie was deeply impressed by the paintings of Velázquez (1599-1660). 
Artistic styles varied from city to city and artists had to study the works of the major schools which required a visit to Florence, Bologna, Venice and Rome. Of all the cities they visited, Rome was the place where they spent most of their time. The second part of this article will be devoted to Scottish painters' activities in Rome. In the city, young artists had various opportunities to study. They could attend classes at the French or Italian academies and they could enrol in the studio of a fashionable painter. They were also able to study the works of art displayed in churches and in private collections, which were easily accessible. Then we shall see the impact of Italian art on eighteenth-century Scottish painters. By focusing on a few paintings and drawings the deep and lasting impact of these Italian journeys on Scottish artists will become evident. Unlike, their English contemporaries, we will see that Scottish painters were not only impressed by the Italian Renaissance masters, indeed some of the major portraitists were influenced by the works of Caravaggio (1571-1610) and his followers. However, the Scots were also inspired by some of the most popular eighteenth-century Italian painters.

Pictorial art only began to develop in Scotland after 1745. The consequences of the Reformation and the Union of Crowns had deprived artists of their main patrons, the Catholic Church and the monarch. As in the other reformed kingdoms, the establishment of the Presbyterian Church in Scotland led to the proscription of religious themes in painting which until then had been the most fruitful field of subject matter for painters in Europe. ${ }^{14}$ Furthermore, the development of painting in Scotland was somewhat hampered by the Kirk as it objected to the opening of public life classes in fine art institutions, which meant that young artists could not draw from nude models and could not gain a sound knowledge of anatomy. Access to patronage became even more hampered when in 1707 the Union of the Parliaments led to the departure of many Scottish aristocrats for London. The demand for paintings was very limited until the beginning of the nineteenth century and, as a result, very few painters opened a studio in Scotland, preferring to work in London. Painters were not the only ones to leave Scotland for England, as in the eighteenth century several leading Scottish literary figures also moved to London in order to have a successful literary career: James Thomson

14. Ian Finlay claimed that: "in the Low Countries Calvinism brought painting down to earth and $[\ldots]$ it created $[\ldots]$ a great school of landscape painting, fully in accord with Calvin's pleasure in Nature as a design of God's creation" (Ian Finlay, Scottish Art, London, Longmans Green and co., 1939, p. 5). In Scotland, landscape painting only began to develop at the end of the eighteenth century. 
(1700-1748) published his Seasons (1730) in London, and it was also in this city that Tobias Smollett (1721-1771) wrote his novels. Others, like James Boswell (1740-1795) and the portraitist Allan Ramsay, travelled regularly between London and Edinburgh. ${ }^{15}$ The painters who decided to remain in Scotland could not live on their artwork alone. With the exception of Raeburn (1756-1823), who had a very successful practice as a portraitist, most painters had to work as decorative painters or they had to sell illustrations to publishers. At the end of the eighteenth century, painters such as Alexander Runciman (1736-1785) and David Allan (1744-1796) also had the option of teaching at the fine art academy in Edinburgh. As very few painters worked in Scotland throughout the eighteenth century, the young Scots aspiring to an artistic career did not often have the possibility to study under a painter and most of them began their training working with a craftsman. Thus the landscape painter Alexander Nasmyth (1758-1840) was apprenticed to a coach painter before studying with Allan Ramsay (1713-1784) in London; Henry Raeburn trained with the jeweller James Gilliland.

Throughout the eighteenth century more and more drawing academies and academies of fine arts were opened on the European continent. ${ }^{16}$ Compared with continental Europe, the creation of such establishments occurred at a much later date in Great Britain: the Royal Academy was opened in 1768 whereas the Académie Royale de peinture et de sculpture had been created in Paris in 1648. However, the Royal Academy was not the first academy of fine arts in Britain. Three art schools had already been established in Scotland, but two of them were short-lived. The Academy of Saint Luke, founded in Edinburgh in 1729, was based on the Roman Academy of the same name. It was created by a few "Painters, and Lovers of Painting [...] for the encouragement of these excellent arts of Painting, Sculpture, Architecture". ${ }^{17}$ This establishment closed down in 1731 and, twenty-two years later, the second Scottish fine art school was opened in Glasgow. The Foulis Academy was created in 1753 by publisher Robert Foulis (1707-1776) with the help of his brother Andrew (1712-1775). The academy's funding being dependent on a few patrons, it had to close down in 1775 following the death of one of the investors in 1770 and the death of Andrew Foulis in 1775. The first permanent Scottish art school, called the Trustees' Academy, was opened in Edinburgh in 1760.

15. Allan Ramsay opened a studio in his father's house in Edinburgh.

16. For more on the development of fine art schools in Western Europe, see Nikolaus Pevsner, Academies of Art: Past and Present, Cambridge, Cambridge University Press, 1940.

17. Quoted in Robert Brydall, Art in Scotland. Its Origin and Progress, p. 110. 
Using John Ingamells' Dictionary of British and Irish Travellers in Italy 1701-1800, and the archives of the Accademia di San Luca in Rome, as well as Jacob More's correspondence and John Ramsay's journals at Edinburgh University Library, ${ }^{18} \mathrm{I}$ have been able to draw up a list of the Scottish painters who went to Italy in the eighteenth century. ${ }^{19} \mathrm{I}$ have included painters in oil, pastellists as well as miniaturists. Among the most prominent Scots to make the journey were Ramsay, Hamilton (1723-1798), Martin (1737-1797), More (1740-1793), Raeburn, Nasmyth and the Runciman brothers. In most cases, they travelled at the beginning of their career before opening their studio, but some of them were already working as professional painters when they went to Italy, as in the case of Henry Raeburn and Alexander Nasmyth. Generally only one visit to Italy was made but there are a few exceptions. Allan Ramsay went to Italy four times. He stayed there from 1736 to 1738 , from 1754 to 1757, from 1775 to 1777 and from 1782 to 1784 . However, only his first two visits had a decisive impact on his art. ${ }^{20}$ Following Ramsay's example, Hamilton went twice to Italy. He studied painting in Rome from 1748 to 1750; back in Britain, he tried to work as a history painter but failed to find patrons and, in 1756, he settled permanently in Italy where he had a successful practice. Hay (d. 1754), Irvine (1757-1831) and Patoun (active 1761-1783) all made a first trip to Italy to study painting, however, when they returned to the Continent, it was no longer as painters - they worked as art dealers or guides for grand tourists.

Travelling and living on the Continent was expensive and not all painters could afford to study abroad for several years. Sometimes they did not hesitate to part with their possessions to go to the Continent:

18. John Ingamells, A Dictionary of British and Irish Travellers in Italy: 1701-1800, New HavenLondon, Yale University Press, 1997.

These are the references of the archives consulted at the Accademia di Luca in which are mentioned Scottish painters. Archivio Storico dell'Accademia di San Luca [hereafter ASASL], Libro originale delle Congregazioni o Verbali delle Medesime, vol. 52, ff. 14, 136 and 139 references to James Byres.

ASASL, Libro originale delle Congregazioni o Verbali delle Medesime, vol. 52, f. 16, about Gavin Hamilton at the Academy.

ASASL, Libro originale delle Congregazioni o Verbali delle Medesime, vol. 54, ff. 136-38, f. 6/b, several references to Jacob More.

ASASL, Libro originale delle Congregazioni o Verbali delle Medesime, vol. 55, f. 71, reference to Jacob More. See also Angela Cipriani and Enrico Valeriani, I Disegni di Figure nell' Archivio Storico dell'Accademia di San Luca, vols 2-3, Rome, Quasar, 1989 and 1991.

Among the documents consulted at Edinburgh University Library, the letters of Jacob More, La. IV. 20, M. 13 ff. 1-44 "Letter Book, 1786-87" and the journals of John Ramsay, son of the painter Allan Ramsay, Mss. 1833-4, "Journals of John Ramsay (11 Dec. 1782 to 5 May 1784)" have been particularly useful.

19. The list is reproduced at the end of this article.

20. His last two trips were entirely devoted to excavations near Tivoli, since Ramsay had injured his right arm in 1773 and he could no longer paint. 
for instance, William Aikman (1682-1731) sold the family estate he had inherited. After the deaths of his father and brother, Aikman became Laird of Cairnie; his relatives wanted him to become a lawyer but instead he was determined to work as a painter. In Edinburgh, he had been a pupil of Sir John Medina (1659-1710) then he moved to London to study in a fine art school. To support himself in London he used the rents from his property in Scotland and from the lands he owned in the British colonies on the Atlantic coast of North America. He also sollicited his uncle Sir John Clerk. To finance his journey to the Continent, he chose to sell his property of Cairnie which enabled him to travel comfortably accompanied by his servant. Aikman arrived in Italy in 1707 and returned to Scotland four years later. ${ }^{21}$ Most painters however had to rely on their patrons to pay for their training abroad. Thanks to the generosity of the Cathcart family, David Allan was able to stay ten years in Italy; in order to go to Rome, Alexander Runciman committed himself to complete, on his return, decorative paintings at Penicuik for his patron Sir James Clerk.

In the eighteenth century, travelling to Italy was a long and hazardous undertaking. ${ }^{22}$ Most travellers approached Italy through France. Once they reached Lyons, they could either cross the Alps and descend to Turin or they could go over land to Marseilles or Nice then they sailed to Genoa or Leghorn. Nevertheless, neither travelling by land nor by sea was an attractive prospect. The crossing of the Alps was dependent on seasonal factors and by sea there was the risk of storms, the risk of Barbary pirates, as well as the inconvenience of contrary winds. Thanks to the journals of Alexander Cunyngham, who travelled with Allan Ramsay, we know that the painter's first continental journey was particularly difficult. Cunyngham gives us a very detailed account of their misfortunes on their way to Rome and explains that in Genoa, in an inn where they stopped for the night, they were robbed by a servant and, shortly after that, while sailing to Rome, their boat was overturned by a storm and they nearly drowned. ${ }^{23}$ Travelling conditions and the number of Scottish painters

21. For an overview of Aikman's career, see James Holloway, "William Aikman, 1682-1731", Scottish Masters, no. 9, Edinburgh, The Trustees of the National Galleries of Scotland, 1988.

22. Travels to the European Continent were not uncommon before the eighteenth century. In the seventeenth century, France and the Dutch Republic were popular destinations with British travellers. For an account of seventeenth-century British travellers in France, see John Lough, France Observed in the Seventeenth Century by British Travellers, Boston, Oriel Press, 1985. For more on seventeenth-century British travellers in the United Provinces, see C. D. Van Strien, British Travellers in Holland during the Stuart Period, Leiden, Brill, 1993.

23. See Mrs Atholl Forbes, Curiosities of a Scots Charta Chest 1600-1800 with Travels and Memoranda of Sir Alexander Dick, Baronet of Prestonfield, Midlothian Written by Himself, Edinburgh, William Brown, 1897. 
going to Italy were also influenced by political events. ${ }^{24}$ During the Napoleonic wars it became extremely hazardous to travel. The war made Italy as unsafe as the French Revolution had already made France and as a result the number of Scottish painters visiting Italy decreased sharply at the beginning of the 1790s. Even though he left Rome before the French invasion, the pastellist Archibald Skirving (1749-1818) had difficulties in returning to his native Scotland. With Britain and France at war, Skirving's boat was captured by the French off the Straits of Gibraltar and suspected of being a spy, he was jailed nine months in Brest. ${ }^{25}$ Even in peacetime, travelling around Italy was long and tedious given the fragmented nature of the various Italian states and travellers were often delayed by the complicated formality of obtaining passports.

The traditional tour of Italy made by eighteenth-century Scottish painters was identical to that undertaken by other foreign artists. They mainly visited Naples, Venice, Bologna and Florence, cities noted for their artistic treasures. In Naples and Florence, British painters were easily granted access to private collections thanks to the diplomacy of Sir William Hamilton (1731-1803), ambassador to the court of Naples from 1764 to 1800, and of Sir Horace Mann (1706-1786), British consul at the court of Tuscany from 1738 to 1786 . Thus in Florence, painters could study the works of art on display in the Grand Duke's Gallery at the Pitti Palace and in the Uffizi. It was from the second half of the eighteenth century, with the discovery of Herculaneum in 1738 and Pompeii in 1748, that Naples began to attract many artists and tourists from all over the Continent. The unearthing of these two ancient Roman towns, as well as the excavations carried out on other antique sites in the Italian peninsula and in the Middle East, led to a heightened awareness of classical antiquity and stimulated a classical revival in the arts. Many books dealing with ancient history, literature and art were published: among others, the Scots James Stuart (1713-1788) and Nicholas Revett (1720-1804) wrote The

24. Thus Jeremy Black has shown that during the conflicts from 1739 to 1748 which led to war between Britain and both France and Spain, as well as during the Seven Year's War (1756-1763) the number of British aristocrats and painters visiting Italy decreased (Jeremy Black, The British Abroad: The Grand Tour in the Eighteenth Century, pp. 8-9). In time of war, tourists sometimes had to modify their itinerary to reach the Italian peninsula. During the Napoleonic Wars, it became almost impossible to travel and the conflict disrupted the Grand Tour.

25. Skirving's sight seemed to have been deeply affected by the months he spent in jail. In 1802, in a letter he sent to his brother, the painter referred to his eyesight problems. He wrote: "What I meant of my sight was, that both eyes were equally strong, for you remember I complained of the right one, but small objects appear forked. At Brest after getting out of prison my companion who would buy some pins at the gate remarked that they were all split; he never dreamed the defect was in his sight, and I cannot make a pen tolerable. Glasses would remedy this but they do not well to paint, for painting requires to see different distances." (Quoted in Stephen Lloyd, Raeburn's Rival. Archibald Skirving 1749-1819, Edinburgh, The Trustees of the National Galleries of Scotland, 1999, p. 22.) 
Antiquities of Athens and Other Monuments of Greece (five volumes were published between 1762 and 1830), Piranesi (1720-1778) published Antichità Romane (1756) and, in France, Comte de Caylus (1692-1765) published seven volumes of Recueil d'Antiquités Égyptiennes, Étrusques, Grecques, Romaines from 1752 to 1767 . But the most influential writings were undoubtedly those of the German Johann Joachim Winckelmann (1717-1768), Reflections on the Imitation of the Painting and Sculpture of the Greeks (1755) and The History of Ancient Art (1764). Indeed, Winckelmann was the leading classical scholar in Europe and when he worked for Cardinal Albani (1692-1779) in Rome he was visited by many tourists and artists. His artistic theories shaped tastes in Western Europe and defined the tenets of neoclassicism, which was the dominant artistic movement in Europe from the second half of the eighteenth to the beginning of the nineteenth century. ${ }^{26}$ Thus many painters, like David Allan, made the journey to Naples to draw from classical sculptures and bas reliefs. Bologna was worth a visit to study the paintings of Reni (1575-1642), the Carraccis and Guercino (1591-1666) which were scattered about the churches and palaces of the town. Quite a lot of Scottish painters also visited Venice to see the works of Titian (1488-1576) and of the other great sixteenthcentury Venetian painters. Some, like Katherine Read (1723-1778), travelled to Venice in order to meet Rosalba Carriera (1675-1757), who was then one of the most famous pastellists in Western Europe. However, of all the Italian cities, Rome was the focus of the Scottish painters' tour, given that the greatest number of ancient, classical sculptures and the masterpieces of Michelangelo (1475-1564) and Raphael (1483-1520), who were then considered as the greatest painters of all time, were concentrated there. Rome also attracted Scottish painters because there was already a Scottish community established in the city. ${ }^{27}$ Since its founda-

26. In painting the first representatives of neoclassicism were Gavin Hamilton and Anton Raphael Mengs. At the end of the eighteenth century, the French Jacques-Louis David became the most influential neoclassical painter. The Venetian Antonio Canova, the Dane Bertel Thorvaldsen and the Englishman John Flaxman (1755-1826) are considered as the most famous neoclassical sculptors. As for architecture, Robert Adam (1728-1792) was the leader of neoclassical taste in Britain. There exist several historical and critical overviews of neoclassicism: see Hugh Honour, Neo-Classicism, Harmondsworth, Penguin, 1968 and David Irwin, Neoclassicism.

27. In the eighteenth century, Scottish communities were established in various parts of Continental Europe - in Holland, France, Scandinavia and Poland among others - as well as in the British Empire. Indeed, Smout has written that: "from at least as early as the Hundred Years War, [...] the Scots were a people quick to seek their fortunes abroad by temporary or permanent migration. It was a national propensity only checked after 1945 by the collapse of the British Empire." (T. C. Smout, "Foreword", Scottish Communities Abroad in the Early Modern Period, Alexia Grosjean and Steve Murdoch (eds), p. v.)

To know more about Scottish communities in Northern and Eastern Europe, see Thomas Fischer, The Scots in Eastern and Western Prussia, Edinburgh, Schulze, 1903 and Jonas Berg and Bo Lagercrantz, 
tion in 1600 by Pope Clement VIII (1536-1605), the Scots College had been the focal point of the community. ${ }^{28}$ Furthermore the number of Scots living permanently in Rome had increased in 1719 with the arrival of the exiled Stuart court. ${ }^{29}$ Thus visiting Scottish painters had a network of compatriots to connect with if they so desired.

Rome had long attracted foreign artists. In the eighteenth century, the role of the city as artistic capital of Western Europe was further strengthened by the growing interest in classical antiquity and, until the French invasion in 1796, an increasing number of painters came to finish off their training. Rome was a cosmopolitan city with tourists and artists coming from all over Europe. Although most artists settled near Piazza di Spagna but, as Olivier Michel underlined in his article entitled "La Vie quotidienne des peintres à Rome au dix-huitième siècle", painters tended to live within their own national communities. ${ }^{30}$ English and Scottish painters met regularly at the Caffé degli Inglesi, but they stayed in different streets, most Scottish painters lived in the Strada Felice. This street lay in the heart of the Scottish community, being the location of the Scots College; it was also very close to the Palazzo Muti, where the exiled Stuart family lived.

The Scots formed a very close-knit artistic community. During the second half of the eighteenth century, young Scots arriving in Rome sought the help and advice of Gavin Hamilton and Jacob More, who had very successful practices in the city. Hamilton was engaged in various activities: he worked as an art-dealer, he carried out excavations on the ancient sites of Ostia, Tivoli, Tor Colombaro and Monte Cagnolo, and

\footnotetext{
Scots in Sweden, Stockholm, the Swedish Institute, 1962. The articles published in Scottish Communities Abroad in the Early Modern Period, Alexia Grosjean and Steve Murdoch (eds), deal with various Scottish communities in Swedish, Polish, Lithuanian, Dutch and Germany cities in the seventeenth century. The presence of Scottish Jacobites in France has been studied in Edward Corp (ed.), A Court in Exile: the Stuarts in France, 1689-1718, Cambridge, Cambridge University Press, 2004.

To know more specifically about the Scottish community in Bordeaux, see Steve Murdoch, "The French Connection: Bordeaux's 'Scottish' Networks in Context, c. 1670-1720", Scotland and Europe, Scotland in Europe, Gilles Leydier (ed.), pp. 26-55.

28. Adam Marks, "The Scots in the Italian Peninsula during the Thirty Years' War", pp. 336-8.

29. Edward Corp has explained that many Scots left Britain after the failure of the Jacobite uprisings in 1715, 1719 and in 1745. The composition of the exiled Stuart court evolved after each of these rebellions and it included an increasing number of Scots. The composition and the life of the exile Stuart court has been studied extensively by Professor Corp. See Edward Corp (ed.), The Stuart Court in Rome: the Legacy of Exile, Aldershot, Ashgate, 2003; Edward Corp (ed.), A Court in Exile: the Stuarts in France, 1689-1718; see also Edward Corp, The Jacobites at Urbino: an Exiled Court in Transition, Basingstoke, Palgrave Macmillan, 2009.

30. Olivier Michel, "La Vie quotidienne des peintres à Rome au dix-huitième siècle", Viore et Peindre à Rome au XVIII siècle, Rome, École française de Rome, 1996, p. 42.
} 
he was also a renowned painter. ${ }^{31}$ He specialised in history painting and was able to find patrons among the British grand tourists for a series of paintings inspired by Homer's Iliad. With his rival Anton Raphael Mengs (1728-1779), Hamilton was the leading history painter in Rome, whose paintings helped establish a taste for Neoclassicism in Western Europe. Indeed, his works were praised by Winckelmann and influenced many artists such as Jacques-Louis David (1748-1825) as well as the sculptors Antonio Canova (1757-1822), Bertel Thorvaldsen (1770-1844) and Tobias Sergel (1740-1814). ${ }^{32}$ As for More, he became one of the most fashionable landscape painters after settling down in Rome in $1771 .{ }^{33}$ His classical landscapes were sought after by British aristocrats and impressed several Scottish painters who met him. When Ramsay stayed in Rome, he was visited by many of his fellow countrymen too. ${ }^{34}$ It was Ramsay who asked his pupil and assistant David Martin to come to Rome in 1755 and, in 1783, it was probably thanks to his former master Ramsay that Nasmyth met More with whom he went drawing landscapes in the countryside. This meeting was extremely important in Nasmyth's career as it encouraged him to give up portraiture for landscape painting. Ann Forbes (1745-1840), Henry Raeburn, James Nevay (c. 1730-after 1811), Nasmyth, John (1744-1768/1769) and Alexander Runciman and David Allan frequented Hamilton's studio. Among all these painters, Alexander Runciman and Allan were the most deeply impressed by Hamilton and when they returned to Scotland they both longed to work as history painters. Thus, the successful career of Hamilton and More and the contact with these artists in Italy encouraged young Scottish painters to specialise in genres other than portrait painting and it helped diversify Scottish painting, which until the end of the eighteenth century was limited to portraiture.

As previously mentioned, whilst in Rome Scottish painters had the option of attending classes at the two prestigious fine art academies of Rome: the Académie de France and the Accademia di San Luca. The French academy in Rome was established in 1666 by Colbert to welcome promi-

31. David Irwin, "Gavin Hamilton: Archaeologist, Painter and Dealer", The Art Bulletin, June 1962, pp. $87-102$.

32. See Robert Rosemblum, "A Source for David's 'Horatii'", The Burlington Magazine, May 1970, pp. 273-4. See also Ellis Kirkham Waterhouse, "The British Contribution to the Neo-Classical Style in Painting", Proceedings of the British Academy, no. 150, 1954, pp. 57-74.

33. For an overview of More's career, see Patricia R. Andrew, Facob More 1740-1793, unpublished Ph.D. thesis, University of Edinburgh, 1981.

34. Aikman of Ross wrote: "Hamilton is what the Italians call the Premiero, and we students call him the Principal, in the Academy of Painting at Rome all the students apply to him for Direction and instruction in their Studies." (Quoted in Julia Lloyd Williams, "Gavin Hamilton, 1723-1798", Scottish Masters, no. 18, Edinburgh, The Trustees of the National Galleries of Scotland, 1994, p. 16.) 
sing young French artists, winners of the Prix de Rome, in order to study art and architecture. Along with the students, foreign artists could attend the daily life classes provided by the French academy from 1725. Apart from a few classes held during the summer by the Accademia di San Luca, the French academy classes were the only public life classes in Rome before 1754, when Pope Benedict XIV (1675-1758) decided to open the Accademia del Nudo under the supervision of the Accademia di San Luca. These life classes, which consisted in drawing from live nude male models, were popular with Scottish painters, for instance, when in Rome, Ramsay regularly attended the classes of the French academy; Alves (1738-1808) and Maxwell, who studied at the Accademia del Nudo, won a prize for their drawings. Before 1836, painters in Scotland had no access to public life classes, while classes held at the Trustees' Academy only used plaster casts of antique sculptures. If artists wanted to draw from a live nude, they could either hire a model or, as David Wilkie used to do, they could draw their own body. Scottish painters were also admitted to the Accademia di San Luca. This academy had been founded in 1593 and was one of the oldest fine art institutions in Western Europe. Unlike the French academy, it did not consistently provide classes before 1754 but painters could copy the collection of paintings and of plaster casts of antique sculptures belonging to the academy. If they were introduced by an academician, painters could also take part in the concorso Clementino and the concorso Balestra, the two competitions organised by the academy. In the eighteenth century, two Scots won these competitions: in 1707 John Taylor was awarded a medal at the concorso Clementino for a drawing and, in 1773, David Allan won the concorso Balestra with his painting entitled Hector's Farewell to Andromache ${ }^{35}$ Winning a prize at the Accademia di San Luca was very prestigious and generally ensured a painter gained important commissions in Rome, however, for Allan this did not seem to have been the case. Being a member of the Academy also helped to find patrons. Gavin Hamilton and Jacob More were the only two Scottish painters to be elected members of the Accademia di San Luca, in 1761 and $1781^{36}$ respectively, and it was probably for this reason that Marcantonio Borghese (1730-1800) hired them to paint one room each in his villa.

Besides the life classes at the academies, many Scottish painters decided to complete their training by working as pupils in the studio of a famous painter. Thanks to the recommendations of the Jacobite Andrew Lumisden

35. David Allan, Hector's Farewell to Andromache, 1773, Accademia di San Luca, Roma.

36. For the election of Hamilton, see ASASL, Libro originale delle Congregazioni o Verbali delle Medesime, vol. 52, f. 16. For the election of More, see ASASL, Libro originale delle Congregazioni o Verbali delle Medesime, vol. 54, ff. 136-7. 
(1720-1801), Byres (1734-1817), Morison (1732-1810), Cunningham (c. 1741-1793), Nevay and Willison (1780-1848) studied under the neoclassical painter Anton Raphael Mengs. Hamilton and Provan worked with Masucci (c. 1691-1758); Mosman (c. 1700-1771) and Ramsay enrolled as pupils in the studio of Francesco Imperiali (1679-1740). The main tasks of young pupils were to improve their drawing technique, to help their masters with their paintings and to copy the works of the great Italian painters. They generally went to copy paintings in churches and some had the permission to study the works of Michelangelo in the Sistine Chapel and of Raphael in the Stanze. Then they often went to study the collection of classical sculptures displayed in the Capitoline Museum and in the Pio-Clementino Museum, which were opened in 1734 and 1771 respectively. The importance of drawing and painting from classical sculptures to their training as is represented in the portrait of Allan ${ }^{37}$ painted by Corvi (1721-1803). Allan, who may have been Corvi's pupil, is shown painting from a cast of the Borghese Gladiator.

As the Scots copied Italian paintings and worked side-by-side with Italian artists in the fine art academies or in their studios for several years, they were naturally influenced by Italian painting.

In the eighteenth century, artists believed in the superiority of Italian Renaissance painting and worshipped Michelangelo and Raphael. In the hierarchy of genres of painting history painting was at that time considered the noblest form of art; young artists who wanted to become successful history painters had to draw their inspiration from the greatest Italian Renaissance and Baroque masters. In addition to Raphael and Michelangelo, they had to study carefully the works of Titian and Correggio (1489-1534) as well as the paintings of Annibale Carracci (1560-1609), Guido Reni and Domenichino (1581-1641), who were the leaders of the baroque style. Thus, in Italy, many Scottish painters made copies after these masters; the work of Raphael and Michelangelo was the most studied by these painters, closely followed by the painting of Carracci and Reni. ${ }^{38}$

The Scots were also interested in other painters who were not popular during the eighteenth century. For instance, Raeburn preferred to study the works of Caravaggio and his followers. In his Ph.D. thesis on

37. Domenico Corvi, David Allan, 1774, Scottish National Portrait Gallery, Edinburgh.

38. Thus, Willison copied the Madonna della Sedia and the Self-portrait by Raphael; Morison and John Alexander copied the School of Athens and Parnassus by Raphael. John Runciman studied carefully Michelangelo and showed his admiration for this Italian master by representing Michelangelo's figure of Day in the background of his self-portrait. 
Raeburn, David Mackie explained that "Raeburn arrived in Rome a virtual beginner [and] he left [Italy] with a mastery of the art of portraiture that was acquired in a surprisingly brief time". ${ }^{39}$ Raeburn's two-year stay in Italy proved very profitable both technically and stylistically as is evident when the portraits he painted before and after his journey are compared. Little is known about Raeburn's activities in Rome, but he painted a David with the Head of Goliath ${ }^{40}$ after Romanelli (1610-1662), a follower of Reni. The scene represented in Romanelli's painting was one of the favourite subjects of Italian baroque painters and the chiaroscuro reminds us of the first paintings of Caravaggio, who produced three paintings representing the victory of David. We do not know if he copied some of his works but he certainly saw paintings by Caravaggio, the inventor of chiaroscuro whose art was at the origin of an aesthetic revolution at the beginning of the seventeenth century. During his lifetime, Caravaggio's works were controversial but he had many followers in Italy, Spain and the Netherlands. In the eighteenth century he was not generally considered as an example to be followed by young artists, yet quite a few Scottish painters copied his paintings: Skirving copied The Cardsharps and the Fortuneteller. ${ }^{41}$ Throughout his career, Raeburn was interested in lighting effects and the use of dramatic contrast between light and shadow apparent in many of his portraits reveals the influence of the Caravaggisti in his works. In the portrait of Patrick Moir, ${ }^{42}$ painted when Raeburn was in Rome, we already find a distinctive interplay of suffused light and deep shadow in small areas which presages Raeburn's interests in the 1790s, when he devised original lighting schemes. A portrait such as Sir Fohn and Lady Clerk of Penicuik ${ }^{43}$ reminds us of the Caravaggisti's paintings because of the intermingling of strong illumination and deep shadow defining shapes. Owing to the range of colours and to the stark contrast between the intense dark of the background and the shaft of light falling from high on the sitter's right, the portrait of

39. David Mackie, Raeburn Life and Art, vol. 1, unpublished Ph.D. thesis, University of Edinburgh, 1994, p. 43.

40. Sir Henry Raeburn after Giovanni Francesco Romanelli, David with the Head of Goliath, c. 1785-1786, location unknown.

41. For several centuries, the majority of artists and art historians shared Nicolas Poussin's point view concerning Caravaggio. Félibien, who personally knew Poussin (1594-1665), wrote that: "Mr Poussin nous en parloit un jour avec grand mépris. Mr Poussin [...] ne pouvoit rien souffrir du Caravage, \& disoit qu'il étoit venu au monde pour détruire la Peinture." (André Félibien, Entretiens sur les Vies et sur les Ouvrages des Plus Excellens Peintres Anciens et Modernes, vol. 3, Amsterdam, 1706, p. 128.) If Caravaggio was not popular with artists and grand tourists, it was because the realism of his paintings was contrary to the idealised beauty advocated by Winckelmann and neoclassical artists.

42. Sir Henry Raeburn, Patrick Moir, c. 1784-1785, National Gallery of Scotland, Edinburgh.

43. Sir Henry Raeburn, Sir Fohn and Lady Clerk of Penicuik, 1792, National Gallery of Ireland, Dublin. 
Margaret Macdonald ${ }^{44}$ is redolent of the paintings of the Caravaggisti. Some of Raeburn's portraits, as well as the works of his countrymen, show that the Scots were also impressed by some the most popular eighteenth-century Italian painters.

The most famous Italian painters working in Rome during the eighteenth century were: Masucci (c. 1691-1758), Chiari (1654-1727), Pozzi (c. 1700-1768), Luti (1666-1724), Imperiali, Benefial (1684-1764), Conca (c. 1680-1764), Trevisani (1656-1746) and Batoni (1708-1787). Today, apart from Batoni who has recently been rediscovered, all these painters have fallen into oblivion. Batoni is best known for his numerous portraits of travellers. Back in the second half of the eighteenth century, he was the most fashionable portraitist in Rome. His main rival was the German Mengs but he was by far the favourite painter of British grand tourists. ${ }^{45}$ At the beginning of his career, Batoni was not specialised in portrait painting. Born in Tuscany, he moved to Rome at the end of the 1720 s and worked in the studios of Conca, Masucci and Imperiali. His reputation was first founded on his drawings and on his history paintings. He completed many altar pieces and devotional pictures for various churches in Rome; he also painted scenes taken from classical history and mythology. From 1754, he produced many portraits of travellers; British tourists were particularly fond of Batoni's portraits representing his sitters with a fashionable air of nonchalance among the most celebrated antiquities of Rome. These portraits particularly influenced Scottish painters. When Gavin Hamilton painted the portrait of the Duke of Hamilton, ${ }^{46}$ he certainly had Batoni's paintings in mind. Indeed, the Duke's pose and the background showing the forum and the Colosseo are reminiscent of Batoni's work. Raeburn's portrait of Moir also seems to have been influenced by Batoni, whom Raeburn may have met thanks to James Byres. This portrait displays smoothness and a degree of finish unusual for Raeburn at the time but which reminds us of Batoni. Batoni's influence is even more obvious on Allan Ramsay. The two portraitists had been friends since the 1730s, when Ramsay met him in the studio of Imperiali and, whenever he was in Rome, Ramsay saw Batoni regu-

44. Sir Henry Raeburn, Margaret Macdonald, Mrs Scott Moncrieff, c. 1814, National Gallery of Scotland, Edinburgh.

45. Batoni's popularity with British aristocrats has been stressed by the exhibition entitled Pompeo Batoni 1708-1787. The Europe of Courts and the Grand Tour held at the Palazzo Ducale of Lucca from 6 December 2008 to 29 March 2009. Liliana Barroero and Fernando Mazzocca, Pompeo Batoni 1708-1787. L'Europa delle Corti e il Grand Tour, Milano, Silvana Editoriale, 2008.

See also Edgar Peters Bowron and Peter Björn Kerber, Pompeo Batoni: Prince of Painters in EighteenthCentury Rome, New Haven-London, Yale University Press, 2007.

46. Gavin Hamilton, Douglas Hamilton, 8th Duke of Hamilton and 5th Duke of Brandon, with Dr Fohn Moore, and Sir Fohn Moore, 1775-1777, National Gallery of Scotland, Edinburgh. 
larly. Ramsay admired his colleague and, in 1782, he sent his son John to study drawing under Batoni. Moreover, it is very likely that Ramsay recommended his former pupil Gabriel Matthias to enrol in the studio of the Italian painter. During his first two visits in Rome, Ramsay copied several of Batoni's drawings and it is in Ramsay's preparatory drawings that the influence of Batoni can best be seen. Indeed Ramsay's studies dating from the 1730s and the 1740s are so reminiscent of Batoni's that art historians had long attributed some of Batoni's drawings to Ramsay. ${ }^{47}$ Ramsay used the same technique as Batoni and their drawings have the same degree of finish and the same delicacy. In A Man's Hand with a Stave, ${ }^{48}$ which is a typical drawing by Ramsay, he, like Batoni, used red and white chalks to convey the play of light and shadow. The parts of the hand on which light is falling are slightly enhanced with white chalk which defines shape; the shadow is represented by intertwining hatchings. Both painters also used red chalk to draw the outlines.

Many, if not most eighteenth-century Scottish painters chose to go into voluntary exile in Italy in order to further their careers. They could not get thorough artistic training in their native country, so if they wanted to become accomplished painters they had no other option but to leave Scotland. Their self-imposed exile generally lasted from one to three years, but thanks to the financial support of their patrons a few painters were able to remain abroad for a longer period. Only two Scottish painters, Jacob More and Gavin Hamilton, decided to settle permanently in Italy. It is possible that they opted for this permanent exile because they had been unable to find patrons for their work in Great Britain, let alone Scotland. Indeed, very few of the Scottish painters who returned to Britain after their sojourn in Italy were able to work in Scotland because of the lack of patronage. In fact most of them went into another exile in order to open a studio in London, the main artistic centre of Great Britain. This time it is debatable as to whether they were in anyway abroad as Scotland formed one component of the British state. However the fact remains that they were forced to work outside Scotland and so involuntary, albeit commercially lucrative exile is still probably the most appropriate term to describe their relocation.

47. For instance, Batoni's drawings Studies of a Child's Head, Left Arm and Right Hand (D 2145, prints and drawings collection, National Gallery of Scotland, Edinburgh) and Studies of Child's Legs, Drapery and a Profile Head of Christ (D 2146, prints and drawings collection, National Gallery of Scotland, Edinburgh) were attributed to Ramsay: Indeed, they are particularly redolent of Ramsay's drawing for the head and shoulders of Prince George (D 1908, prints and drawings collection, National Gallery of Scotland, Edinburgh).

48. Allan Ramsay, D 2144, prints and drawings collection, National Gallery of Scotland, Edinburgh. 
Returning from their exile in Italy, these migrants transformed the Scottish artistic world despite the fact that the majority settled in England rather than "home". Their training abroad contributed to the development and diversification of Scottish painting through the influence it had on other British painters and upon the new academies which were developed in Scotland in the later eighteenth century. These painters had not only improved technically, they were also deeply influenced stylistically by ancient and contemporary Italian art, and their return to Britain ensured future generations would be exposed to both the styles and techniques they picked up abroad. Today, Scottish painting is very often compared with Dutch painting, but until the end of the eighteenth century the influence of Italian painting is clearly visible on Scottish art, and that is in no small part due to the return of the artistic exiles.

\section{List of Scottish painters (including miniaturists and pastellists) who visited Italy between 1701 and 1800}

Aikman William (birth: 1682-death: 1731): in Italy from 1707-1711.

Alexander Cosmo (1724-1772): 1747-1752.

Alexander John (1686-c. 1766): 1711-1719.

Allan David (1744-1796): 1767-1777.

Alves James (1738-1808): 1762-1771.

BROWN John (1747-1789): 1771-1780.

Byres James (1734-1817): 1758-1790.

Chalmers George (c. 1723-1791): c. 1750-1753.

CLERK James (c. 1745-1800): 1768-1800.

CLerk Alexander (fl. 1729-1737): 1736-1737.

Cochran William (1738-1785): c. 1761-1766.

COCKBURn Patrick: 1726-1727.

COOPER Richard (c. 1740-1814): 1771-1776.

Cunningham Edward Francis (c. 1741-1793): c. 1745-1765.

DAY John "MacGilp" (c. 1736-1807): 1756-c. 1765.

ERsKine Colin (Nicholas) (c. 1705-1740): 1733(?)-1740.

ERSKINE David: 1775-1780.

Forbes Anne (1745-1840): 1767-1771.

Foulis James (1770-1842): 1790-1794.

Graham John (c. 1706-c. 1775): 1726-1727.

GUTHRIE: 1735.

Hamilton Gavin (1723-1798): 1748-1750 / 1756-1798.

HAY Andrew (d. 1754): 1716-1717 / 1718 / 1720-1722.

IRVINE James (1757-1831): 1780-1791 / 1797-1798. 
MacLauchlan Archibald (fl. 1762-after 1770): c. 1762.

Marshall George (d. 1732).

Martin David (1737-1797): 1755-1757.

MAXwell James: 1758.

MoIR John (1775-1859): 1792-1797.

More Jacob (1740-1793): c. 1773-1793.

Morison Colin (1732-1810): 1754-1810.

Mosman William (c. 1700-1771): c. 1733-1740.

NASMyth Alexander (1758-1840): 1783-1784.

NevaY James (c. 1730-after 1811): 1755-1811.

Patoun William (fl. 1761-d. 1783): 1761-1763 / 1763-1764 / 17681769 / 1773-1774 / 1777.

Provan Samuel: 1748.

RAEBURn Henry (1756-1823): 1785-1787.

RAMSAY Allan (1713-1784): 1736-1738 / 1754-1757 / 1775-1777 / 1782-1784.

READ Katherine (1723-1778): 1751-1753.

Ross George (birth c. 1691?): 1713-1720.

Runciman Alexander (1736-1785): 1767-1771.

Runciman John (1744-1768/1769): 1767-1768/1769.

SkIRVING Archibald (1749-1818): 1787-1794.

SMiBert John (1688-1751): 1719-1722.

TAYLOR John: c. 1707.

WILLISON George (1741-1797): 1760-1767.

WILSON Andrew (1780-1848): 1799-1803. 